\title{
Investment policies and competitiveness of Azerbaijani economy
}

\author{
Fikrat M.Pashayev
}

Khazar University, Baku, Azerbaijan

\section{Peculiarities of economic development process in Azerbaijan}

After restoration of its independence in 1991 Azerbaijan had faced developmental dilemma - to be satellite of some big country and imitate transition recommendations or create its own independent development model based on analysis of world experience with effective use of national resources. The second way was easy to declare but difficult to realize since external political and economic environment was not in favour of independent thinking and decisionmaking. Notwithstanding external pressure, the country's leadership was able to choose second way, and therefore economic development process included not only mere transformation from previous inefficient system of centrally planned economy to market economy but also use of various proactive policies in order to realize competitive advantages, mainly existing natural resources and geographical location. Those policies were related to trade and investment, industrialization, diversification, social development, institutional building and good governance. Government approach and action plan was based on adherence to general recommendations by experts from international institutions, foreign government and academia in combination with country-specific measures and policies. As a result, the Azerbaijan made remarkable bounce in development that some experts may determine as unique example.

During the recent two decades the country has achieved substantial economic and political progress. GDP grew from $\$ 5.2$ billion in 2000 to $\$ 63.4$ billion in 2011 and GDP per capita reached $\$ 7,003$ in 2011 (The State Statistical Committee of the Republic of Azerbaijan, www.azstat.org), one of the highest in the region of Caucasus and Central Asia (for comparison in 2000 GDP per capita was \$662). According to the World Bank statistics between 2000 and 2009 Azerbaijan enjoyed double digit growth in GDP, with amazing 26.4\%, 34.5\% and 25.05\% accordingly 
in 2005, 2006 and 2007 (www.worldbank.org). The collapse of Soviet Union, subsequent political instability and armed conflict with neighboring state adversely affected Azerbaijani economy and the country experienced double-digit negative growth at early years of independence (1991-1995), but political and economic stabilization, structural changes and attraction of FDI in oil sector helped economy to bounce back starting 1996.

As soon as Azerbaijan started to receive oil revenues Government strongly supported special programs aimed at poverty reduction, development of region and growth of employment. In his opening speech at the Meeting of the Cabinet of Ministers on the result of socio-economic development in 2011, President of the Republic of Azerbaijan Ilham Aliyev stated more than one million jobs have created since the since the program against unemployment have been launched in 2003. Poverty [that amounted 49\% in 2000] level fell to 7.6 percent in 2011 (www.president.az).

\section{Investment climate in the country and national development objectives in attracting Foreign Direct Investment (FDI)}

Economic success of Azerbaijan was based on Government's proactive investment policy in combination with gradual increase of the role of market, with low inflation and macroeconomic stability. National competitive advantage was created through selective industrial policy, where oil and gas sector was a core. Subsequently, state and foreign direct investment played a crucial role in industrial development and diversification of economy

At early stages, attraction of FDI and growth in foreign trade became possible through market reforms, introduction of new legislation according to international standards and establishment of relevant state agencies regulating process of economic development. Signed oil and gas contracts provided best incentives for foreign oil multinationals, which started invest heavily in Azerbaijan. This allowed to get substantial oil revenues in short time period and gave the Government opportunity to start to invest domestically and abroad.

In order to create favorable investment climate Azerbaijan adopted Law on Protection and Promotion of Foreign Investment in 1992. The Government also signed bilateral investment treaties and bilateral tax treaties with many countries. Building basis for FDI, Azerbaijani Government conducted structural reforms and introduced several important pieces of legislation, such as Tax Code, Land Code, Customs Code, Labour Code, etc. 
According to the Ministry of Economic Development of Azerbaijan, investment climate in the country is defined by the Laws of the Republic of Azerbaijan on "Investment activity" and on "Protection of Foreign investments" accordingly. To improve investment climate simplified system of registration of business called "single window", privatization options and land lease regulations for foreign investors, simplified licensing, taxation and customs regulations were introduced (www.economy.gov.az).

Oil and gas sector became engine of development due to country's effective oil strategy which was based on attraction of investment of large multinational technologically advanced oil companies. This was mutually beneficial and provided balance of interests since the host country received oil revenues and best technologies and companies shared risk and increased profits. Besides that, Azerbaijan gave all necessary guaranties for investors in oil and gas sector.

Attraction of FDI to oil and gas sector was very complex since mutually beneficial economic cooperation came across with geopolitical interests of global and regional players. First oil contract was signed on 20 September 1994 and since that time 26 PSA contracts were signed with multinationals from various countries. Long lasted discussion over the main export pipeline route (eventually BTC) delayed construction of pipeline [till 2004] and relevant development of major offshore oil and gas fields. Interestingly, that was even more beneficial for Azerbaijan because oil prices skyrocketed since 2004 bringing Azerbaijan much more revenues in shorter period of time. The Government created State Oil Fund and uses oil revenues for diversification of economy and development of large infrastructural projects

According to Azerbaijan Export and Investment Promotion Foundation (AZPROMO) publications (www.azpromo.az), during 1995-2011 the country attracted 63.1 billion USD of foreign investment, and FDI accounted to 41.4 billion USD. With domestic investment of 55.5 billion for the same period the economy of Azerbaijan benefited from 118.6 billion USD of total investment. Oil and gas sector received 48.5 billion USD and non oil sector 70.1 billion USD.

Main investors in the country are countries whose oil companies are engaged in explorations of oil and gas field in Azerbaijan, such as BP, Statoil, Total, Exxon, Itochu, Lukoil and others. Today major FDI source countries are USA, UK and Turkey. Cumulative FDI totaled 3.6 billion USD in 2010 and 4.4 billion USD in 2011.

FDI outside the oil and gas sectors are mainly in construction, services, transport, telecommunications and manufacturing. In 2010 FDI mainly came from 
Netherlands (26\%), Turkey (24\%), UK (23\%), USA (7\%), Germany (3\%) and Switzerland (2\%) - AZPROMO, Azerbaijan in figures 2010()

Azerbaijan investment attraction policy can be called success today, since despite very complex geo-political environment the country managed to create favorable investment climate and attracted multibillion dollar investment in various sectors of its economy. Quality of economic management and political Governance are significant factors in Azerbaijan's economic success. Political stability and competence of the political leadership played important role in raising country's credibility. Policies pursued since mid-1990s created strong macroeconomic environment characterized by high savings and low inflation. Establishment of State Oil Fund of Azerbaijan (SOFAZ) allowed accumulation of oil and gas revenues with a purpose of saving money for future generations and diversification of economy. The low-inflation environment reflects prudent monetary and fiscal policies and opened doors for rational investment policies.

In Azerbaijan we can see combination of foreign investment (FDI in particular) and domestic investment. However, the question is how advantageous are domestic investment vis-à-vis foreign, and what should be best investment options in defining sector development policies? FDI, especially if they done by large multinationals enterprises definitely bring the country more technology, managerial skills and external market channels. Domestic investment still could be reasonable if they are using advanced technologies and know-how of MNEs [non-equity forms - subcontracting, management agreements, franchising, licensing, etc.] or come in combination of FDI [consortia agreements, portfolio investment, joint ventures]. We have already seen such combination in realization of oil and gas contract, it is time now to spread it to other sectors.

The World Investment Report 2011 introduced by United Nations Trade and Development Agency (UNCTAD) is entitled "Non-equity modes of international production and development" and specifically analysis important role of nonequity forms of cooperation and MNE penetration. Currently new, non-equity forms of MNE penetration are playing important role in Azerbaijani economic development. Together with $100 \%$ control and joint ventures, licensing, management contracts, franchising, became popular in Azerbaijan. This is mainly derived from globalization and growing attractiveness of Azerbaijani economy.

Another interesting phenomenon of the recent years is growing Azerbaijani investment abroad. Large investment in energy sectors of Turkey and Georgia could be good examples. That can be explained by the fact that Azerbaijani market 
is too small and foreign markets are attractive, especially due to global financial crisis and economic slowdown.

Diversification of Azerbaijani economy will require development of human resources. To provide industrial workforce, Azerbaijan started to modernize its education system. It would be advisable to look at the experience of some other successful countries, such as Singapore for example, which since 1960s started to make emphasis on technical vocational education (Chia Siow Yue, 2005). Government of Azerbaijan already started paying attention to industrial development. In Sumgait, city near capital Baku industrial site has emerged. This industry will definitely need trained workforce. Therefore technical and vocational education and specialized industrial training institutes are necessary elements for industrial development.

Italy can be helpful in this area, since lack of qualified workforce will result in growing import of labour power from abroad making national workforce uncompetitive and out of game. Tertiary education is also necessary element of education in general since in can provide professionals and managers in science, engineering, business and computing. At initial stage recruiting of foreign talent is necessary both for public and private sectors. This should be gradually changed in favor of local labour force. Azerbaijan may use experience of newly industrialized countries that introduced English as language of instruction in schools and universities facilitating the operations of MNCs in Azerbaijan and linking Azerbaijan with global economy.

\section{Competitiveness of Azerbaijani economy and changes in its economic structure}

Azerbaijan's natural competitive advantages are based on 4 major factor resources, such as (1) oil and gas resources and ability for their development, (2) strategic geographical location at the crossroads in the heart of Eurasian continent, (3) diversified and favorable climate for agribusiness, (4) rich history and culture. These factors have been inherited, and before re-gaining independence in 1991 never used properly for nations benefit. Initial competitive advantage derived from Azerbaijan's geographical location and natural [oil and gas] resources was supported by the Government's trade and investment policies.

For many years oil sector has been pillar of economy of Azerbaijan, while agriculture and service have not been developed adequately. Inadequate technological basis and lack of financial resources made it impossible to develop oil and gas sector without participation of large Multinational Enterprises (MNE). After large investment into oil and gas sector, covering mostly extraction and 
transportation of crude oil and natural gas, structure of Azerbaijani GDP and export/import operations shifted towards domination of oil and gas sector. According to International Monetary Fund, Republic of Azerbaijan, 2011 Article IV Consultation (www.imf.org) in 2011 oil sector accounted for more than $90 \%$ of export of Azerbaijan, and share of oil sector in industry was $85 \%$. According the World Bank data for Azerbaijan in 2010, shares of industry, agriculture and services in Azerbaijani economy were accordingly 64.72\%, 5.75\% and 29.53\% (www.worldbank.org).

Government initially promoted investment in oil and gas sector [discovery, extraction, processing and transportation] and subsequently started focus on development of non-oil sectors: noin-il manufacturing, services and agriculture. In services sector, the priority was development of world class transportation and telecommunications infrastructure and facilities. Multimodal (air, sea, railway and road) transportation and telecommunications networks will allow Azerbaijan link major cities and ports in Eurasian continent.

President of Azerbaijan stated in his speech at the Meeting of the cabinet of Ministers on the result of socio-economic development in 2011 that despite the fact that due to oil production decrease in 2011 GDP grew only $0.1 \%$, non-oil sector grew $9.4 \%$ that shows right strategy of Government in investing in non-oil sector. Increase in non-oil industry and in non-oil sector in general became possible since both local and foreign investment substituted $\$ 37$ billion in just two years (20102011). This increase will be even more impressive as economy of Azerbaijan will became export-oriented and foreign direct investment based economy.

Thus, in last two decades, the economy of Azerbaijan has moved from ineffective centrally planned economy to market oriented, capital abundant one. The country has become an important oil and gas producer and exporter in the Caspian Sea region, and steadily moving towards becoming major regional trading, transportation and telecommunications hub. Development of oil and gas sector, that often is called as "engine of economy" in combination with some unexpected positive externalities at the world market, such as oil price rise, had positive impact on other sectors, including industry, services and agriculture. Growing domestic investments into these sectors in combination with FDI and non-equity forms of MNE penetration created favourable conditions to further technological advance and Government policy is aimed at industrial structure to progress towards capital and technology- intensive manufacturing.

Policy of the Government to attract local investment and FDI in non-oil sector sooner or later will demand effective shift from import substitution policy to export 
oriented one. For that reason, Azerbaijan will needs to increase competitiveness of its economy and advance to the stage of innovation driven economy. Recently published by World Economic Forum the Global Competitiveness Report 20122013 (www.weforum.org) ranks Azerbaijan 46 among 144 countries (9 positions up comparing to the last year). Despite the progress achieved, Azerbaijan still stay at the transition stage from factor driven economy to efficiency driven one.

According to this indicator (see picture below) Azerbaijan does very well in providing macroeconomic environment and labor market efficiency. Lacking areas are technological readiness, innovation, market size, infrastructure, institutions, financial market development, and business sophistication. Assuming that the path from factor driven economy takes some time, Azerbaijan's progress is very positive. Meanwhile, modernization of economy through FDI and advanced technologies will require substantial investment in education and professional training, as well as additional incentives for business sophistication and

\section{Stage of development}
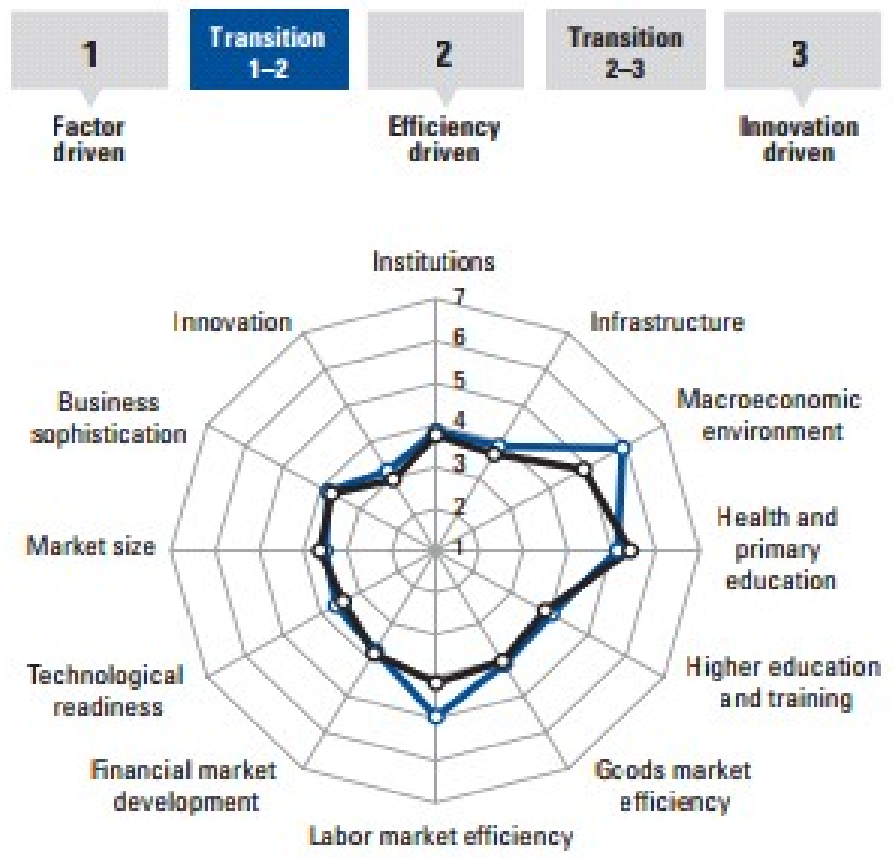

- Azerbaijan $-\infty$ Economies in transition from 1 to 2

innovations. 
Source: WEF Global Competitiveness Report 2012-2013

Business environment in the country has been substantially improved during recent years. International Finance Corporation "Doing Business" 2012 Report placed Azerbaijan $66^{\text {th }}$ among 183 nations ahead of such neighboring countries as Turkey, Russia, Romania, Iran , Ukraine and regional average (Eastern Europe and Central Asia - 77). However, Azerbaijan can easily improve further in this area. The strong parts of indicator where Azerbaijan advances are "Starting business" (18), "Registering property" (9), "Enforcing contracts" (25) and "Protecting investors" (24). Weak elements are "Getting electricity" (173), "Getting construction permit" (172) and "Trading across borders" (170). As we can see, improvement in these 3 elements can substantially improve business climate in the country.

Import sophistication could play dual role: it can lead to decrease of residents' income level although having positive effect of regional GDP per capita (Martins Priede, 2012), at the same time it can also define directions for import substitution. To compete with more highly qualitative foreign goods at the domestic market, local companies have to apply better technologies. This is impossible without FDI and cooperation with leading MNEs on equity and non-equity basis. Local companies acquiring advanced technologies and joint ventures can replace import needs at more effective manner. This is also could be justification and necessary step for further export oriented manufacturing.

Industrial development, diversification of economy and growth of competitiveness will require trade liberalization and therefore accession to the World Trade Organization (WTO) will become necessary element in increasing of national competitiveness. Some may argue that small post transition economies acceded to WTO several years ago made unjustified commitments and either suffered global financial crises and economic slowdown or didn't show any substantial economic growth performance. That view can be justified, especially taking into account practice of treating transition economies as "developed" instead of "developing" and it deprives them from certain advantages [amount of agriculture subsidies for example] after acquiring membership. At the same time, gradual accession of neighboring states, especially Russia, doesn't leave choice but entering WTO to use its multilateral trading system mechanism to protect local exporters at the time when their products will be more sophisticated and competitive on foreign markets.

\section{Conclusions}


During last two decades Azerbaijan made remarkable achievements in developing its statehood and economy. Despite the difficult political environment, the Government was able to conduct rational policies and attracted foreign investment in oil and gas sector that became engine of development. Country's current economic policies and strategies aimed at lessening of dependence on mineral sector through policies of diversification, development if regions and growth of business and employment in non-oil sector.

Domestic investments in industrial development, infrastructure and education, could ensure sustainable economic growth, especially in non-oil sector of economy. State will play important role in creation of favorable investment climate, pursuing structural reforms, maintaining macroeconomic stability, negotiating beneficial conditions for accession to WTO and diversification of economy

Sustainability of Azerbaijani economy will require increase in competitiveness and shift towards technologically advanced and innovation friendly production with balanced approach to manufacturing, services and agriculture. All these sectors of economy could bring comparative advantage for Azerbaijan if rational policies will be successfully implemented. Expansion of these sectors will require both domestic and foreign investment, especially FDI as a major form of foreign investment. At the same time, for getting better results in diversification of economy FDI can be complemented by various non-equity forms of cooperation, such as subcontracting, licensing and franchising.

\section{References and notes:}

[1] Opening speech by Ilham Aliyev at the Meeting of the cabinet of Ministers on the result of socio-economic development in 2011, January, 2012, Baku, Azerbaijan, www.president.az

[2] Фикрет Пашаев (2006) “Транснациональные корпорации и закономерности развития межфирменных связей”, [Fikret Pashayev "Transnational Corporations and patterns of development of inter-firm relations"], Baku, 2006

[3] United nations Conference on Trade and Development - UNCTAD - World Investment Report 2011 - Non-equity modes of international production and development, United nations New York and Geneva, 2011 (www.unctad-docs.org)

[4] Martins Priede (2012) Import Impact of Economic Growth on regional economies, 2012 International Conference on economics marketing and management, Singapore, 2012

[5] Chia Siow Yue (2005) "The Singapore model of industrial policy: past evolution and current thinking". Paper for presentation at the Second LAEBA Annual Conference, Buenos Aires, 28-29 November 2005 
[6] The State Statistical Committee of the Republic of Azerbaijan, www.azstat.org

[7] Ministry of Economic Development of the Republic of Azerbaijan, www.economy.gov.az

[8] "Doing business in Azerbaijan 2011", “Azerbaijan in figures 2010”, Azerbaijan Export and Investment Promotion Foundation (AZPROMO) - www.azpromo.az

[9] The World Bank, Data and Statistics for Azerbaijan, web.worldbank.org

[10] International Finance Corporation. Doing Business report, www.doingbusiness.org

[11] The World Economic Forum, Global Competitiveness Report 2012-2013 (www.weforum.org)

[12] International Monetary Fund, Republic of Azerbaijan, 2011 Article IV Consultation (www.imf.org) January 18, 2012

\title{
Summary
}

\section{Investment policies and competitiveness of Azerbaijani economy}

\section{Fikrat M.Pashayev}

\author{
Khazar University, Baku, Azerbaijan
}

\begin{abstract}
Azerbaijan has made remarkable achievements in economic growth due to rational investment policies and attraction of foreign investment in oil and gas sector that became engine for development. Country's current economic policies and strategies aimed at lessening of dependence on mineral sector through diversification, growth of business and employment in non-oil sector. Sustainability of Azerbaijani economy will require shift towards technologically advanced and innovation friendly production with balanced approach to manufacturing, services and agriculture. It is advisable to pursue policy of attraction of FDI into these sectors in combination with various non-equity forms of cooperation, such as subcontracting, licensing and franchising.

Italy and Azerbaijan have very good basis and instruments for cooperation. However, Italian companies have to be more proactive in finding areas for investment and considering participation in various developmental projects. Cooperation on equity and non-equity basis and experience of Italy in developing SME could be right directions for expansion of economic cooperation.
\end{abstract}

Key words: Azerbaijan economy, economic growth, foreign investment, non-oil sector 